\title{
COMMON SKINK Eutropis carinata (REPTILIA: SCINCIDAE) FEED ON ENDEMIC SEMI-SLUG Ratnadvipia irradians (LIMACOIDEA: ARIOPHANTIDAE)
}

${ }^{1}$ IUCN Sri Lanka Country office, No. 53, Horton place, Colombo 07, Sri Lanka

${ }^{2}$ Taprobanica Nature Conservation Society, 146, Kendalanda, Homagama, Sri Lanka

${ }^{2}$ Corresponding author: aathasun@gmail.com

The skinks belong to the genus Eutropis is widely distributed in South and South East Asia and is represented in Sri Lanka by seven species, the largest and the most common of which is common skink Eutropis carinata (Schneider, 1801) (Das et al., 2008). In Sri Lanka E. carinata is widely distributed in open areas, closed canopy forest, home gardens and plantations in wet and dry zones below 1,000 m altitude (Das \& de Silva, 2005). The Sri Lankan endemic semi-slug genus Ratnadvipia consists of two species, Ratnadvipia irradians (Pfeiffer, 1853) and Ratnadvipia karui Raheem \& Naggs, 2006. Ratnadvipia is almost exclusively confined to the tropical lowland rain forests, intermediate zone and up to the suitable habitats within the dry zone (Raheem \& Naggs, 2006). Although snails are usually not an item of skink diet, we have observed a semi-slug in E. carinata gut.
On $30^{\text {th }}$ December 2008, a dry sunny day, first author found a dead (road kill) of Eutropis carinata adult male (snout-vent length $143 \mathrm{~mm}$, tail length $202 \mathrm{~mm}$ ) on the rocky road at Morningside area, Ratnapura District $\left(06^{\circ} 24^{\prime} \mathrm{N}, \quad 8^{\circ} 38^{\prime} \mathrm{E}\right.$, altitude $1030 \mathrm{~m}$ ) at $07: 15 \mathrm{hr}$ (temperature $23{ }^{\circ} \mathrm{C}$, humidity $69 \%$ ). The specimen was fresh with severe head damage. The abdomen of the skink was dissected and investigated the gut contents. The lumen of the stomach consisted of an undigested adult specimen of Ratnadvipia irradians (total length of the body: about $60 \mathrm{~mm}$, maximum width of the shell: about $18 \mathrm{~mm}$ ) (Fig. 1) in addition to six half digested Coleopterans.

We have frequently observed $R$. irradians at Morningside Forest. This species is mostly observed on the leaves of cardamom (Elettaria cardamonium) bushes, on shrubs as well as on rotting 